\title{
Ibn Khaldun's Religionswissenschaft: Exploring the Sources in the Muqaddimah
}

\author{
Wan Mohd Fazrul Azdi Bin Wan Razali ${ }^{\text {** }} \&$ Jaffary Awang ${ }^{\mathrm{b}}$ \\ ${ }^{a}$ Lecturer, Akidah and Religion Studies Programme, Faculty of Leadership and Management, Universiti Sains \\ Islam Malaysia \\ ${ }^{b}$ Associate Professor and Head of Department, Department of Theology and Philosophy, Faculty of Islamic \\ Studies, Universiti Kebangsaan Malaysia \\ *Corresponding author: wmfazrul@usim.edu.my \\ Article history \\ Received: 2016-10-13 \\ Received in revised form: 2016-12-02 \\ Accepted: 2016-12-04
}

\begin{abstract}
Ibn Khaldun is one of many Muslim scholars in the study of Islamic history and civilization, who is popularly known for his Muqaddimah. The Muqaddimah is meant to be an introduction to the voluminous Kitab al- ${ }^{c} I b a r$. Yet, the creation of Muqaddimah includes information on the study of human, which includes information on the non-Muslim religions. By including information on the non-Muslim religions in his Muqaddimah, this means that there are specific sources used by Ibn Khaldun for this purpose. In any research writings, credible and reliable sources of information are among important elements in determining a valid, useful and accurate research finding. Through the use of qualitative content analysis on Muqaddimah text, this article explores Ibn Khaldun's sources of information on the non-Muslim religions. Two typologies of Ibn Khaldun's sources are relayed in this article, namely their main forms and their religious origin. In terms of main forms of sources, there are two main forms of sources found in the Muqaddimah, namely critical observation and textual sources. While for their religious origin, Ibn Khaldun's sources of other religions could be divided into three main types, namely first, Muslim sources, second, Christian sources and third, Jewish sources. This article opines that these sources are proofs of Ibn Khaldun's epistemology, altogether of his understanding of knowledge and religion, as integrative or in tawhidic manner. It is possible to conclude that due to this integrative or tawhidic understanding, Ibn Khaldun's Muqaddimah has been recognized as amongst world's great literatures and referred by many international scholars until today.
\end{abstract}

Keywords: Ibn Khaldun, Religionswissenschaft, Muqaddimah, sources and integrative. 
Wan Mohd Fazrul Azdi \& Jaffary Awang / UMRAN - International Journal of Islamic and Civilizational Studies. 04-01 (2017) 67-79

\subsection{INTRODUCTION}

Ibn Khaldun is one of many Muslim scholars in the study of Islamic history and civilization. Ibn Khaldun's full name is al-'Allāmah Walī al-Dīn Abū Zayd 'Abd al-Raḥmān ibn Muhammad ibn Khaldūn (Ibn Khaldūn 1979 and Mohammad Abdullah Enan 1997:3). Ibn Khaldun was born in Tunis on 1 Ramaḍān 732AH / 27 May 1332AD (Ibn Khaldūn 1979 and Schmidt 1978:34). He was a "medieval scholar famed for his philosophy of history and insights into the rise and fall of civilizations" (Campo 2009:334). This genius Muslim figure is popularly known for his unique magnum opus, namely Muqaddimah. The Muqaddimah is unique as stated by Oliver Leaman as follows: "The Muqaddima is intent to put everything in its place" (Zaid Ahmad 2003: x-xi).

According to ${ }^{c}$ Abd al-Raḥmān Badwī (1917-2002), a prominent Egypt biographer and historian, there are eight writings which are ascribed to Ibn Khaldun ( ${ }^{\mathrm{c} A b d}$ al-Raḥmān Badw̄ī 2006). In brief, these eight writings of Ibn Khaldun are as follows: 1) Lubāb al-Muhașșal Fì Ușūl al-Dīn, 2)

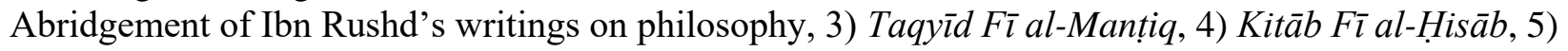
al-Hilal al-Marqūmah Fī al-Luma al-Manżūmah, 6) Commentary of al-Būṣirīs Qașīdah al-Burdah, 7) Shifā' al-Sā'il F̄̄ Tahdhīb al-Masā' 'il, and lastly is his magnum opus 8) Diwān al-Mubtada' wa alKhabar F̄̄ Ayyām al- ${ }^{c}$ Arab wa al- ${ }^{c}$ Ajam wa al-Barbar wa Man ${ }^{c} \bar{A}$ șarahum Min Dhaw̄̄ al-Sultān alAkbar. This includes two important fractions from the Diwān, namely Muqaddimah and al-Tacriff Bi Ibn Khaldūn Wa Riḥlatuhu Gharban Wa Sharqan (al-Ṭabbā ${ }^{\mathrm{c}}$ 1992:54-59 and ${ }^{\mathrm{c}} \mathrm{Abd}$ al-Rahman Badwi 2006:33-77).

\subsection{IBN KHALDUN'S RELIGIONSWISSENSCHAFT}

The Muqaddimah is principally meant to be an introduction to the voluminous text of Maghrib history, namely Kitab al- ${ }^{c} I$ Ibar. Yet, the creation of Muqaddimah includes information on the study of human, which simultaneously includes information on Religionswissenschaft. Religionswissenschaft is originally German language for the 'Science of Religion' or the 'Study of Religion.' It is a firmly rooted academic discipline and constituted by other disciplines of knowledge as its methodology of study, for example the history of religions, sociology of religion, anthropology of religion, psychology of religion and phenomenology of religion (Pummer 1972:91 and Ort 1968:191-192).

Ibn Khaldun's purpose for the creation of Muqaddimah is actually related to the purpose of writing his Tārīkh. This is due to the fact that Muqaddimah is the first volume of his Tārìkh, namely Diwān al-Mubtada' wa al-Khabar F̄̄ Ayyām al-- Arab wa al-'Ajam wa al-Barbar wa Man 'Āṣarahum Min Dhawī al-Sulțān al-Akbar (n.d.). Ibn Khaldun elaborates that his purpose for the creation of Muqaddimah is to analyse and describe the history of the Arabs and the Berbers in Maghrib. He states:

"I based the work on the history of the two races that constitute the population of the Maghrib at this time and people, its various regions and cities, and on that of their ruling houses, both long-and short-lived, including the rulers and allies they had in the past. These two races are the Arabs and the Berbers (Ibn Khaldun 1967 1:10-11)."

Though the Muqaddimah is principally meant to be a lengthy introduction to the voluminous text of history of the Maghrib, nevertheless, the creation of the book also includes information on the study of human. In one way or another, the study of human could never escape from touching the instrumental aspects of religions from being discussed. Human history is not only made from cultural, political, commercial and educational activities, but also religious. In Ibn Khaldun's words, his remarks are as follows:

"Therefore, today, the scholar in this field needs to know the principles of politics, the (true) nature of existent things, and the differences among nations, places, and periods with regard 
to ways of life, character qualities, customs, sects, schools, and everything else... He must be aware of the differing origins and beginnings of (different) dynasties and religious groups, as well as of the reasons and incentives that brought them into being and the circumstances and history of the persons who supported them (Ibn Khaldun 1967 1:55-56)."

The same path was also shown by the previous famous Muslim historiographers and historians,

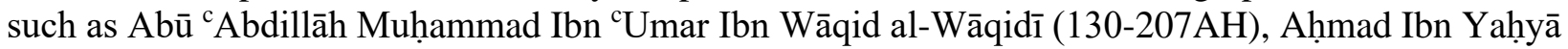

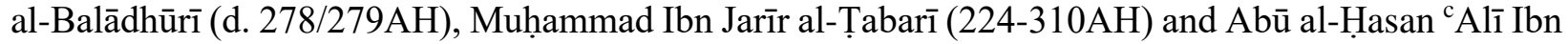
Husayn Ibn ${ }^{\mathrm{c}} \mathrm{Al} \overline{\mathrm{i}}$ al-Mas ${ }^{\mathrm{c}} \overline{\mathrm{u}} \mathrm{d} \overline{1}$ (282/283-345AH), which their works were referred by Ibn Khaldun. For instance, though al-Wāqidī's Kitāb al-Maghāzī (1984) focuses on the history of war during the days of the Prophet Muhammad PBUH, however he also includes the details of other religions, especially of the Mushrikūn (polytheists) of Mecca (al-Wāqidī 1984). The same also goes to al-Balādhūrī, alTabarī and al-Mas ${ }^{\mathrm{c}} \overline{\mathrm{u}} \overline{\mathrm{i}}$, where their studies of religions have caught the attention of some modern researchers. Specifically, al-Mas ${ }^{\mathrm{u}} \overline{\mathrm{u}} \overline{\mathrm{i}}$ 's study of other religions has been discussed by modern scholars such as Ahmad Shboul (1979), Sulaymān ' Abdullāh al-Shuwaykat (1986), and Majdan Alias' (2011) through their theses and journal articles.

Ibn Khaldun's study of other religions here refers to his expositions and clarifications of the religions of Judaism, Christianity, Magianism, and Sabeanism. This also includes Ibn Khaldun's views on religion, such as his views on the interrelationship between ${ }^{c}$ asabiyyah and religion, on al-nas ${ }^{c}$ ala dīn mulükihim (the common people follow the religion of their rulers), al-insan ibn ma'lüfihi wa ${ }^{c}$ awà 'idihi la tabĩcatihi wa mizäjihi (human is a child of his customs and not of his natural disposition), al-Imāmah Wa al-Dīn (leadership and religion), and Ghāyah al-Hayāh ya ${ }^{c} n \bar{\imath} a l-S a^{c} \bar{a} d a h$ Fì al-Dīn (the purpose of life, which is happiness is in religion) (Ibn Khaldun 1967 and Ibn Khaldūn 2014).

Furthermore, there are also previous researches and academic papers by modern scholars of religious study and historiography that highlight the same discussions on the study of religions in the Muqaddimah. These scholars discuss on multiple aspects related to Ibn Khaldun's study of religions such as his study of Judaism, Christianity, Jesus, Bible and views on religion. For instance, Walter J. Fischel (1902-1973), Solomon Pines, Kalman Bland, Steven M. Wasserstrom, Muhammad Azizan Sabjan and Martin Whittingham concentrate on the specific issues, such as Ibn Khaldun's usage of Jewish sources and his knowledge of the Bible (Fischel 1958:147-171; Pines 1970:265-274; Bland 1983:189-197; Wasserstrom 1999:164; Muhammad Azizan Sabjan 2010; and Whittingham 2011:209222). Whilst scholars such as Bryan S. Turner, Charles Issawi (1916-2000) and Syed Omar Syed Agil discuss on Ibn Khaldun's views on the role that religion plays in society, politics, culture and economics (Turner 1971:32-48; Issawi 1963:131 - 139; Black 2005:165-182 and Syed Omar Syed Agil 2008:301-307). In praising Ibn Khaldun's study of other religions, Walter J. Fischel, a scholar of Oriental Jewry and Islamic studies of the University of California, says:

Ibn Khaldun's detailed knowledge of early church history shows how and to what degree he, the orthodox Muslim, could detach himself from the fetters of his own faith and penetrate into the theological and doctrinal differences of another religion. Indeed among the ArabMuslim scholars who attempted such a study, it was Ibn Khaldun, the great Muslim thinker of the fourteenth century, who achieved astounding scholarly objectivity in regards to the various non-Islamic religions (Fischel 1967:137).

\subsection{SOURCES ON THE OTHER RELIGIONS IN THE MUQADDIMAH}

By including information on non-Muslim religions in his Muqaddimah, this means that there are specific sources used by Ibn Khaldun for this purpose. In any research writings, credible and reliable sources of information are among important elements in determining a valid, useful and accurate 
research finding. Through the use of qualitative content analysis on Muqaddimah text, this article explores Ibn Khaldun's sources of information on the non-Muslim religions as enshrined in this work.

There are two typologies of Ibn Khaldun's sources, namely their main forms and the religious origin of these sources. In terms of these sources main forms, there are two main forms of sources found in the Muqaddimah, namely critical observation and textual sources. Whilst, in terms of religious origin, Ibn Khaldun's sources of other religions could be divided into three main types, namely first, Muslim sources, second, Christian sources and third, Jewish sources.

Figure 1: Two typologies of Ibn Khaldun's sources

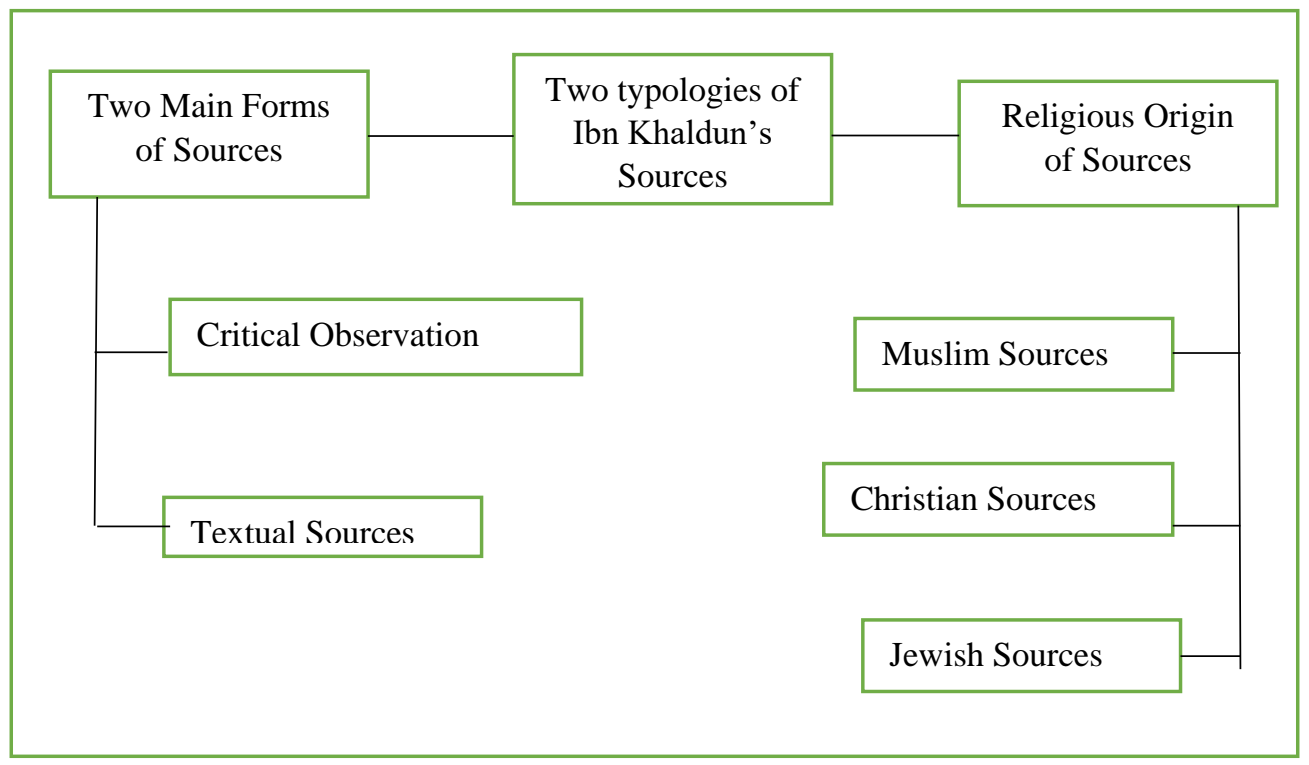

\subsection{Two typologies of Ibn Khaldun's Sources}

Ibn Khaldun's purpose for the creation of Muqaddimah, as aforementioned in the previous paragraph, is to produce a historical book of his own, which corrected the problems and wrong facts in the books by previous historians such as al-Wāqidī, al-Ṭabarī, and al-Mas ${ }^{\mathrm{c}} \overline{\mathrm{d}} \mathrm{i}$. "For Ibn Khaldun, therefore, historical ideas should reflect reality; that is, they should conform to, or cohere with, the rules that govern social organisation" or known as the "umrān science (Donnelly and Norton 2011: 29). The reality or truth, as understood by Ibn Khaldun, is made up from the deeper knowledge of the 'cause and reason for an event,' whereby not only from 'just knowing the event' (Ibn Khaldun 2014). Towards this purpose, his endeavour requires many sources of knowledge such as suggested in this article, namely: critical observation and textual sources.

\subsubsection{Critical Observation}

Most scientific pursuits for knowledge are not only acquired through experimentation and examination. Scientific pursuits that rely on empiricism also include observation as one of its methodologies. By observation here, it refers to a scholarly learning from an attentive watch over a significant event for a period of time. Some benefits of observation are direct access to the subject of study and giving the whole view of the subject of study, including its location, action and environment (Hammond and Wellington 2013: 111-114).

In Faghirzadeh's analysis, critical observation is considered as the first source of data in any sociological undertakings. Information or results from the observation must be weighed for their consistency with the universal principles in many disciplines of knowledge, namely psychology, history, 
biology, geography and logic (Saleh Faghirzadeh, 1982: 21-22). Ibn Khaldun uses observation in determining the nature and attributes of social phenomenon, which enriches his grasp and discussions on history. Observation to Ibn Khaldun is used not only for collection of information per se, but also for comparative study between nations, between periods of time and also to unveil the reason for an event $\left({ }^{\mathrm{c}} \mathrm{Al} \overline{\mathrm{i}}\right.$ cAbd al-Wāhid Wāfĩ 2014: 199-202 and Muhsin Mahdi 2016). In Saleh Faghirzadeh's analysis: "IbnKhaldun believed that scientific research requires (1) accurate observations; (2) logical and objective methods; (3) gathering data from the present or past; (4) careful recording and (5) the courage of careful description and reporting" (Saleh Faghirzadeh 1982: 18).

In describing Ibn Khaldun's observation, it consists of two important levels: first, observation on the workings of any social activities and events. Second, observation on the reason for these social activities and events ( ${ }^{\mathrm{c}} \mathrm{Al} \overline{1}{ }^{\mathrm{c}} \mathrm{Abd}$ al-Wāhid Wāfì 2014: 200). Specifically, Ibn Khaldun travels and journeys, along the North African and Arab counties enriched his observation and research for his Muqaddimah. For instance, his visit to Spain in meeting Pedro, a Christian leader of Granada; visit to Jerusalem, and befriended Abraham Ibn Zarzar, a Spanish Jew scholar of his time; all these were among the experiences that filled his observation on the other religions (Fischel 1967; Ibn Khaldūn 1979; Nāṣ̂̄f Nașșār 1981; al-Nabhān 1998). In praising Ibn Khaldun, Philip K. Hitti (1886-1978), a Professor of Arabic studies at Princeton University describes:

"His strength lies in his first hand, intimate knowledge of North Africa-Arab and Berber-Egypt, and Granada, all of which he treats with an amazing degree of restraint and objectivity. Rarely does he flatter a personal friend or be little an enemy (Hitti 1968: 251)."

It is worth noting here that although Muslims were the major population of the countries where Ibn Khaldun journeyed through and stayed; there also existed other non-Muslim communities such as the Jews, Christians, Magians, and Sabeans. This is also evidently prescribed in the Qur'ān and historical texts (al-Qur'ān al-Karīm, al-Baqarah 2:67; al-Hajj 22:17; Hitti 1946; Tritton 2008; LevyRubin 2011). For instance, in the Qur'ān, Allah clearly lists six different religions as follows: Islam, Judaism, Christianity, Sabeanism, Magianism (al-Majūs) and polytheism (al-Mushrikūn). Allah says: "Surely those who believe and those who are Jews and the Sabeans and the Christians and the Magians and those who associate (others with Allah) - surely Allah will decide between them on the day of resurrection; surely Allah is a witness over all things" (al-Qur'ān al-Karìm, Sürah al-Hajj 22:17). It is possible to say here that these four non-Muslim communities, namely Judaism, Christianity, Sabeanism, and Magianism; which are mentioned in his Muqaddimah are probably based from this specific verse of the Qur'ān.

According to Philip K. Hitti, even in the pre-Islamic period, the Arab land is the cradle of the Semites, which represents an international relation between people of various languages, cultures and religions such as Egyptians, Sumerians, Babylonians, Assyrians, Persians, Hebrews, Sabaeans and Nabataeans (Hitti 1946:3-86). Whilst, in the studies by A. S. Tritton and M. Levy-Rubin on the Covenant of ${ }^{c}$ Umar R.A., both describe that Muslim relationship with the non-Muslim has begun as early in the period of the Prophet PBUH and further developed during the expansion of Islamic empire (Tritton 2008; Levy-Rubin 2011). Therefore, a critical observation on religions along the North African and Arab countries could unveil various religions, including these six faiths as addressed in the previous paragraph. It is interesting to note here that the same focuses on these six religions are also made by some earlier Muslim historians or predecessors of Ibn Khaldun such as al-Tabarī (224-310AH / 839-923AD) in his Tārīkh al-Rusul wa al-Mulūk (2007), al-Mas ${ }^{\mathrm{u}} \overline{\mathrm{u}} \mathrm{i}$ (d. 346AH / 957AD) in his Murūj al-Dhahab Wa Macādin al-Jawhar (2005) and Ibn al-Athīr (544-606AH) in his al-Kāmil Fī alTārīkh (1987).

There are many places in the Muqaddimah, where Ibn Khaldun exhibits his critical observation on religions and its related matters. For instance, in all religions, being good is considered as among the main teachings. In comparing between the Bedouins or the Nomads from the sedentary or the city 
people, according to Ibn Khaldun, the Bedouins are closer to being good than the sedentary people. This argument is justified by Ibn Khaldun in subchapter four of chapter two of his Muqaddimah from using his critical observation on the lives of both communities, namely the Bedouins and the sedentary people. Sedentary people are concerned with all sorts of pleasures such as life luxury, occupation and worldly desires. Due to these kinds of pleasures, their souls are inflicted with bad qualities, which eventually caused them to lose their self-restrain or self-control over lustful matters. Whilst, the Bedouins are only concerned with the needs and the necessities of life. Being not exposed to the luxurious life, their self-restrain or self-control over lustful matters is well maintained. Furthermore, they are tightly bound to follow the traditional customs of the Bedouin life. Interestingly, this fact or theory is also perceived by Ibn Khaldun to relate with his theory of stages of civilization decay. He asserts: "It will later on become clear that sedentary life constitutes the last stage of civilization and the point where it begins to decay. It also constitutes the last stage of evil and of remoteness from goodness. It has thus become clear that Bedouins are closer to being good than sedentary people" (Ibn Khaldun 1967; Ibn Khaldūn 2014).

Another example of Ibn Khaldun's critical observation is found in subchapter twenty-three of chapter two in his Muqaddimah. Here, the title says: Fì Anna al-Maghlūb Mūlac Abada Bi al-Iqtidā' Bi al-Ghālib F̄̄ Shicārihi Wa Ziyyihi Wa Niḥlatihi Wa Sā'ir Ahwwālihi Wa ${ }^{c} A w a \bar{a}$ 'idihi (which means: the vanquished always want to imitate the victor in his distinctive mark(s), his dress, his occupation, and all his other conditions and customs). In this specific discussion, Ibn Khaldun uses one of his favourite theories or maxims to justify why the oppressed or the colonized is accustomed to follow its oppressor or colonizer, namely: al ${ }^{c} \bar{A} m m a h{ }^{c} A l \bar{a}$ Dinn al-Malik, which means: the common people follow the religion of the ruler. He justifies his theory and discussion here from his observation on two events. First is the influence imposed by parents to their children, second, is the influence imposed by the Galicians (the ruler) over the Spaniards (the people) in terms of their dress, emblems, and most of their customs. Based on both events, both the children and the Spaniards are psychologically and culturally enforced to follow their superiors. Therefore, if there is any question why the subordinates are prone to imitate their superiors, Ibn Khaldun's answer is for one to look at the psychological and cultural factors including education, laws, custom and inner feeling (Ibn Khaldun 1967; Ibn Khaldūn 2014). Evidently, such rationalization by Ibn Khaldun in unveiling the reasons why subordinates are prone to imitate their superiors is achievable through critical observation.

\subsubsection{Textual Sources}

Following the tradition of other scholars of history or historiography, Ibn Khaldun also utilizes a large number of texts for the creation of his Muqaddimah and Tārīkh. In the modern study of history, generally, sources of history could be divided into two main types, namely primary and secondary sources. Primary sources are the main sources for historical research, namely first hand source of information of any undertaken historical study such as manuscript, government report, archaeological findings, or stone inscription. Whilst, secondary sources are the writings of other historians that are related to the undertaken historical research such as textbook, journal article, and historical research report (Collingwood 1970; Shafer 1974; Qasim Ahmad 1991; Berg 2001; Ishak Saat 2010; Donnelly and Norton 2011).

According to Fischel's analysis of Tārīkh or Kitāb al-'Ibar, Ibn Khaldun's sources of other religions could be divided into three main types, namely first, Muslim sources, second, Christian sources and third, Jewish sources (Look: Figure 1: Two typologies of Ibn Khaldun's sources). Muslim sources here include 1) the Qur'ān, 2) Hadīth, 3) works of al-Ṭabarī, 4) al-Mas'ūì̄, 5) al-Suddī, 6) Suhaylī, 7) Ibn al-Kalbī, 8) Ibn Isḥāq, 9) al-Bayhaqī, 10) Ibn Sa ${ }^{c} \overline{1} d$ al-Maghribī, 11) Ibn 'Asākir, 12) 
Hamzah al-Așfahānī, 13) Hasan al-Bașrī, 14) al-Jurjān̄̄, 15) Ibn Qutaybah, 18) Ibn Hazm, 17) alShahrastānī, 18) Ibn al-Athīr, 19) Abū al-Fidā' and others (Fischel 1967, 116).

Among Ibn Khaldun's Christian sources are 1) Canonical Gospels, 2) The Book of Jacob, 3) Ibn al- ${ }^{c} A m \bar{d}$ 's Majmū' al-Mubārak, 4) Tārīkh of Abū Shākir Buṭrus and 5) work of al-Musabbih̄ī, 6) work of Eutycus (Sa`̄īd ibn Bițīq) and 7) Paulus Orosius' Historiae Adversus Paganos. Whilst, among Ibn Khaldun's Jewish sources are 1) Torah, 2) Isrā'īliyyāt of Himyarites Jew converts (such as Kacb alAhbar and Wahb ibn Munabbih) and 3) Hebrew Chronicle of Yüsuf ibn Kuryūn (Fischel 1967, 116119). For example, Ibn Khaldun confesses his reference to the Torah as follows:

$$
\begin{aligned}
& \text { وقد توهم بعض النسابين ممن لا علم لدياه بطبائع الكائنات أن السودان هم ولد حام بن نوح اختصهوا }
\end{aligned}
$$

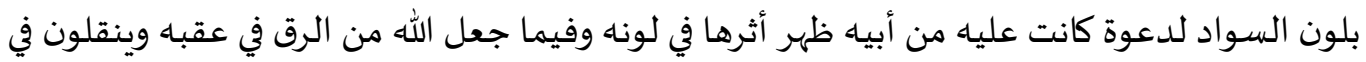

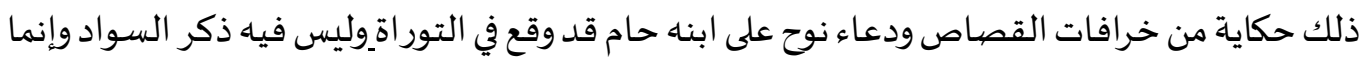

$$
\begin{aligned}
& \text { دعا عليه بأن يكون ولده عبيداً لولد إخوته لا غيراه. }
\end{aligned}
$$

Which means: Genealogists who had no knowledge of the true nature of things imagined that Negroes are the children of Ham, the son of Noah, and that they were singled out to be black as the result of Noah's curse, which produced Ham's colour and the slavery God inflicted upon his descendants. It is mentioned in the Torah (Genesis 9: 25) that Noah cursed his son Ham. No reference is made there to blackness. The curse included no more than that Ham's descendants should be the slaves of his brothers' descendants (Ibn Khaldun 1967).

In the previous paragraph, it is clear that Ibn Khaldun refers to the Torah in authenticating whether there is any curse into black made by Noah in the Torah upon his son, Ham. Obviously, in the Torah, there is no curse upon Ham to turn into black is mentioned, except Noah's curse that Canaan (son of Ham) to be the slave of his other brothers (Shem and Japheth). This is evident in the story of Noah mentioned in the Torah, Genesis 9:18-29 as follows:

[18] And the sons of Noah, that went forth from the ark, were Shem, and Ham, and Japheth; and Ham is the father of Canaan. [19] These three were the sons of Noah, and of these was the whole earth overspread. [20] And Noah the husbandman began, and planted a vineyard. [21] And he drank of the wine, and was drunken; and he was uncovered within his tent. [22] And Ham, the father of Canaan, saw the nakedness of his father, and told his two brethren without. [23] And Shem and Japheth took a garment, and laid it upon both their shoulders, and went backward, and covered the nakedness of their father; and their faces were backward, and they saw not their father's nakedness. [24] And Noah awoke from his wine, and knew what his youngest son had done unto him. [25] And he said: Cursed be Canaan; / A servant of servants shall he be unto his brethren. [26] And he said: Blessed be the Lord, the God of Shem: / And let Canaan be their servant. / [27] God enlarge Japheth, / And he shall dwell in the tents of Shem; / And let Canaan be their servant. [28] And Noah lived after the flood three hundred and fifty years. [29] And all the days of Noah were nine hundred and fifty years; and he died. (Hebrew-English Tanakh The Jewish Bible 2009, Genesis 9:18-29).

In addition, this study also analyzes ${ }^{c} A \overline{1}^{\mathrm{c}} \mathrm{Abd}$ al-Wāḥid Wāfî’s Alphabetical Index (al-Fihrist alAbjadī) of Ibn Khaldun's Muqaddimah and finds that there are one hundred and three written works cited by Ibn Khaldun in his Muqaddimah (Ibn Khaldun 2014 3:1338-1407). These written works include great masterpieces of many disciplines in Islamic sciences such as: Murüj al-Dhahab Wa $M a^{c} \bar{a}$ din al-Jawhar of Abū al-Hasan ${ }^{\mathrm{c}} \mathrm{Al} \overline{\mathrm{i}}$ ibn al-Husayn al-Mas ${ }^{\mathrm{c}} \overline{\mathrm{u}} \mathrm{d} \overline{\mathrm{i}}$ (d. 346AH / 957AD) in history, alAhkām al-Sulțāniyyah Wa al-Wilāyāt al-Dīniyyah by Abū al-Hasan ${ }^{\mathrm{c}} \mathrm{Al} \overline{\mathrm{i}}$ ibn Muhammad al-Māwardī (364-450AH / 974-1058AD) in Islamic politics, al-Burhān Fī Ușül al-Fiqh by ${ }^{\mathrm{c}} \mathrm{Abd}$ al-Malik ibn Yusuf al-Juwaynī (419-478AH) in Islamic principles of jurisprudence, and Ihy $\bar{a}{ }^{~}{ }^{c} U l \bar{u} m$ al-Dìn by al-Ghazālī (450-505AH) in Islamic Sufism. 
Interestingly, from all these one hundred and three written works, two cited works are identified as main written works in the Muslim study of religions, which are referred by Ibn Khaldun for his Muqaddimah. These two Muslim works are al-Fișal Fī al-Milal wa al-Ahwā' wa al-Nihal by Ibn Hazm al-Zāhirī (384-456AH / 994-1064AD) and al-Milal wa al-Nihal by ${ }^{\mathrm{c}}$ Abd al-Karīm al-Shahrastānī (476548AH / 1086-1153AD). These two works are among main references for the Muslim scholarship in the study of religions. For instance, al-Fișal Fì al-Milal wa al-Ahwā' wa al-Nihal describes the teachings of non-Muslim religions such as Judaism, Christianity, and also highlights some positions of Islam on the teachings of these both religions (Ibn Hazm 1996). Whilst, al-Shahrastānī's al-Milal wa al-Nihal is more like an early Muslim encyclopaedia of other religions, which describes the histories and teachings of world religions such as Judaism, Christianity, Magianism, Sabeanism, Mazdakiyyah, Mānawiyyah and Hinduism (al-Shahrastānī 1993).

Despite of the one hundred and three written (103) works mentioned in the Muqaddimah, it is possible to believe that Ibn Khaldun also refers to other sources of textual materials on other religions. This is possible based on reading Ibn Khaldun's Tärīkh, which also includes many other written works which are not mentioned directly in the Muqaddimah. The Muqaddimah is in reality a prolegomenon to the whole voluminous Tärīkh or Kitab al- ${ }^{c} I b a r$. This means that there are more references of Ibn Khaldun for the Muqaddimah through the whole voluminous Tärikh or Kitab al- ${ }^{c} I b a r$, than only those mentioned in the Muqaddimah.

For example, in Ibn Khaldun's second volume of Tārīkh or Kitab al-' Ibar, he mentions sources such as from al-Ṭabarī (224 - 310AH / 839 -923AD), Ibn al-Athīr (544-606AH) and al-Tawräh (Torah) by mentioning 'qāla al-Tabarī, qāla Ibn al-Athīr and fì al-Tawrāh.' It should be noted here, as also suggested by Fischel and other researchers on Ibn Khaldun's study of other religions, it is in the second volume of his Tärīkh or Kitab $a l-^{c} I b a r$ that Ibn Khaldun puts forward many information regarding other religions such as Judaism, Christianity, Sabeanism and Magianism (Ibn Khaldun n.d.; 2000). However, this article does not look into details to the volumes of Ibn Khaldun's Tärīkh or Kitab $a l-^{c} I b a r$, due to the fact that this study only focuses on Muqaddimah. Yet, this study suggests that this possibility might be worth taken into investigation, in other studies especially in tracing the sources of reference used by Ibn Khaldun in his study of other religions.

\subsection{IBN KHALDUN'S INTEGRATIVE OR TAWHIDIC EPISTEMOLOGY}

From analysing Ibn Khaldun's sources for the non-Muslim religions, this article opines that these sources are not merely references for Ibn Khaldun's Religionswissenschaft. Nevertheless, they are also proofs of Ibn Khaldun's epistemology, altogether of his understanding on the relationship between knowledge and religion, as integrative or in tawhidic manner. Integrative or tawhidic manner here means that Ibn Khaldun's epistemology, which regards both naqli (revealed) and 'aqli (rational) knowledge are complementing each other. It is possible to conclude that due to this integrative or tawhidic understanding that Ibn Khaldun's Muqaddimah has been recognized as amongst world's great literatures and referred by many international scholars until today.

Many Muslim scholars generally sourced to Islamic revelations, namely al-Qur'ān al-Karìm and al-Sunnah al-Nabawiyyah in understanding other religions. For both al-Qur'ān al-Karìm and alSunnah al-Nabawiyyah are not only replete with information on specific and focused discussion of Islamic beliefs and practices, but also convey a lot of information on the other religions. For instance,

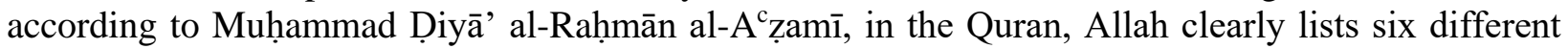
religions as follows: Islam, Judaism, Christianity, Sabeanism, Magianism (al-Majūs) and polytheism (al-Mushrikün) in the verse 17, Sürah al-Hajj, chapter 22. Interestingly, almost one third of the Quran 
covers the stories of these religions, namely mentioning the beliefs, practices, sources of these religions and information of their deviation from the way of truth (al- $\left.A^{c} z a m \overline{1} 2003: 16\right)$.

In this sense, Ibn Khaldun also refers to the al-Qur'ān al-Karìm and al-Sunnah al-Nabawiyyah for such information in his Muqaddimah, which includes here his information on the other religions. In this study, an analysis was made on the Indexes of Quranic Verses and Prophetic Traditions (Fihrist al-Āyāt al-Qur'āniyyah wa Fihrist al-Ahāāith wa al-Äthār) in Abū Șuhayb al-Karamī's review of Tarīkh Ibn Khaldūn. This study found that out of 224 Qur'ānic verses cited in Ibn Khaldun's Tärīkh or Kitab al-'Ibar, 144 verses were addressed in the first volume or in the Muqaddimah. Whereas for Prophetic traditions (al-Sunnah al-Nabawiyyah), out of 303 Prophetic traditions cited in Ibn Khaldun's Tărīkh, 158 Prophetic traditions were addressed in the Muqaddimah (Ibn Khaldun n.d.: 2127-2139).

Statistically, more than half of Qur'ānic verses and Prophetic traditions, which are cited in Ibn Khaldun's Tārīkh or Kitab al- ${ }^{c} I b a r$, could be found in his Prolegomena or in the Muqaddimah. Most of the time, Ibn Khaldun uses these Qur'ānic verses as the final sentences for his written chapters and subchapters. These Qur'annic verses are used as his final sentences to relate to the discussion he addressed in the main text, showing his mastery of both naqli (revealed) and ${ }^{c} a q l \bar{\imath}$ (rational) sciences; or his integrationist way.

Nevertheless, this study recognizes that there are disagreements between scholars in the Khaldunian studies, especially among the Western orientalist in acknowledging the integrationist or tawhidic way of Ibn Khaldun throughout his Muqaddimah. For instance, Fuad Baali and Ali Wardi in their analysis of Muqaddimah, claim that "Ibn Khaldun was completely secular or realistic in his thought-style. When he discusses purely religious matters, he jumps surprisingly from a materialistic attitude to a spiritual one, from rationalism to mysticism" (Fuad Baali and Ali Wardi 1981: 28 and Ali Husayn Wardi 1950). In the words of Lutfi Sunar and Faruq Yaslicimen:

The major difficulty in the anachronic readings of Ibn Khaldun appears to be the misinterpretations in Ibn Khaldun's comprehension of religion. One of the pioneering sociologists in Turkey, Ziyaeddin Fahri Findikoğlu (1951:69-71) states that there are two dominant opinions in the orientalist literature about Ibn Khaldun's understanding of science and religion. According to the first opinion, every single social phenomenon that Ibn Khaldun discusses is connected with the Holy Qur'an and consequently connected with the will of God. On the other hand, the defenders of the second opinion argue that Ibn Khaldun, though carried the good manners of Islamic education as a sincere Muslim, interpreted the social phenomena in a realist way depending on reason and experiment. Accordingly, he used the verses of the Qur'an as justificatory tools for escaping from possible bigoted reactions. The primary representatives of the first group in the modern scholarship were H.A.R. Gibb and G. Richter; while the representatives of the second group were Gumplovicz and A. Von Kremer (Lutfi Sunar and Faruq Yaslicimen 2008, 415).

From analysing Muqaddimah, especially on its Chapter Six that discusses on branches of knowledge, this study opines that Ibn Khaldun's epistemology, altogether his understanding of knowledge and religion is of integrationist or tawhidic way. Integrationist or tawhidic here means in a manner that regards both naqli (revealed) and ${ }^{c} a q l \bar{l}$ (rational) knowledge that complementing each other. This is evident from his use of sources throughout the Muqaddimah, which sourced to the Qur'ānic verses and Prophetic traditions in various places. Furthermore, in his description of various sciences that exist in his time in Chapter Six of Muqaddimah, he clearly signifies both types of sciences as follows: first, philosophical sciences (al- ${ }^{c} U l \bar{u} m$ al-Falsafiyyah al-Hikmiyyah) and second, traditional-conventional sciences (al- ${ }^{c} U l \bar{m}$ m al-Naqliyyah al-Wad $\left.{ }^{c} i y y a h\right)$. Ibn Khaldun says:

The various sciences that exist in contemporary civilization. It should be known that the sciences with which people concern themselves in cities and which they acquire and pass on through instruction, are of two kinds: one that is natural to man and to which he is guided by 
Wan Mohd Fazrul Azdi \& Jaffary Awang / UMRAN - International Journal of Islamic and Civilizational Studies. 04-01 (2017) 67-79

his own ability to think (al- ${ }^{c}$ Ulüm al-Falsafiyyah al-Hikmiyyah), and a traditional kind that he learns from those who invented it (al- ${ }^{c}$ Ulüm al-Naqliyyah al-Wad'iyyah) (Ibn Khaldun 1967).

These both are two main types of knowledge that became the concern of people in Ibn Khaldun's time, which they are acquired through the means of education, and passed on through generations from teaching and learning (Ibn Khaldun 1968; al-Husșī 1968, 485-508; 'Imād al-Dīn Khalīl 1983; alShik ${ }^{c}$ ah 1992; Ibn Khaldūn 2014). In other words, it is impossible for Ibn Khaldun to list such detailed information of both naqli (revealed) and ${ }^{c} a q l \bar{\imath}$ (rational) knowledge, without firstly studying and learning them.

Any reader of Muqaddimah could find such rich information provided by Ibn Khaldun in his lines of word. Ibn Khaldun's exposition and discussion of an issue or topic sometimes could be penetrated from many disciplines of knowledge, namely philosophy, history, economics, sociology, psychology and politics. In Schmidt's word:

\begin{abstract}
"In examining the factors of history he does not look only without, but also within. He extends his researches into the psychological realm... Even religion, so far as it manifests itself, he draws within the circle of man's social life. He recognizes, but does not exaggerate, the importance of the individual psyche and the group psychology. If there is a positive philosophy, based on the ascertainable facts of science, Ibn Khaldun is, in spite of his Muslim orthodoxy, a philosopher as much as Auguste Comte, Thomas Buckle, or Herbert Spencer. His philosophy of history is not a theodicy as Hegel's. There are indeed numerous quotations from the Koran, inserted in appropriate connections. They may have been designed to give the impression of accordance with Holy Writ (Schmidt 1978:24)."
\end{abstract}

In sum, his unique method in treating history as his focus of study, so as in treating religious issues, was shaped through his exceptional scholarship achievement in many fields, namely: ${ }^{c} a q \bar{l} d a h$, fiqh, tașawwuf, history and philosophy. By combining his maturity and steadfastness in all disciplines of study, he also embarks on the 'why', instead only on the 'what' and 'how' questions. For that reason, he evidently subscribes his method as scientific, which he calls as 'umrān study (Ibn Khaldun 2005 1:56; Ibn Khaldun 1967 1:77-78; Ibn Khaldun 2002: Lxviii). In short, his ${ }^{c} u m r a \bar{n}$ study attempts to bring together the revealed (naqlī), rational $\left({ }^{c} a q l \bar{\imath}\right)$ and empirical (tajrīb $\left.\vec{\imath}\right)$ research methods into his sociohistorical study of religions. Conclusively, such paradigm is of paramount importance for an indepth research, especially in proposing Islamic science for this postmodern era.

\title{
6.0 CONCLUSION
}

To conclude, Ibn Khaldun is one of many Muslim scholars in the study of Islamic history and civilization. This genius Muslim figure is popularly known for his unique magnum opus, namely Muqaddimah. The Muqaddimah is principally meant to be an introduction to the voluminous text of Maghrib history, namely Kitab al- ${ }^{c} I b a r$. Yet, the creation of Muqaddimah includes information on the study of human, which simultaneously comprises of information on Religionswissenschaft or the 'Study of Religion.'

There are two typologies of Ibn Khaldun's sources of other religions, namely their main forms and their religious origin. In terms of these sources main forms, there are two main forms of sources found in the Muqaddimah, namely critical observation and textual sources. Whilst, in terms of religious origin, Ibn Khaldun's sources of other religions could be divided into three main types, namely first, Muslim sources, second, Christian sources and third, Jewish sources.

From analysing Ibn Khaldun's sources for the non-Muslim religions, this article opines that these sources are not merely references for Ibn Khaldun's Religionswissenschaft. Nevertheless, they are also proofs of Ibn Khaldun's epistemology, altogether of his understanding of knowledge and religion, as 
Wan Mohd Fazrul Azdi \& Jaffary Awang / UMRAN - International Journal of Islamic and Civilizational Studies. 04-01 (2017) 67-79

integrative or in tawhidic manner. Integrative or tawhidic manner here means that Ibn Khaldun's epistemology, which regards both naqli (revealed) and ${ }^{c} a q l i \bar{l}$ (rational) knowledge are complementing each other. It is possible to conclude that due to this integrative or tawhidic understanding that Ibn Khaldun's Muqaddimah has been recognized as amongst world's great literatures and referred by many international scholars until today.

\section{REFERENCES}

${ }^{c}$ Abd al-Raḥmān Badwī. (2006). Muallafāt Ibn Khaldūn. Cairo: al-Majlis al-A' lā Li al-Thaqāfah.

Ahmad Shboul. (1979). Al-Mas'udi and His World. London: Ithaca Press.

Al-A'ẓamī, Ḍiyā’ al-Raḥmān. 2003. Dirāsāt Fi al-Yahūdiyyah Wa al-Nașrāniyyah Wa Adyān al-Hind. Riyadh: Maktabah al-Rushd Nāshirūn.

Al-Ḥușrī, Abu Khaldun Sātic. (1968). Dirāsāt ${ }^{c} A n$ Muqaddimah Ibn Khaldun. Cairo: Maktabah Al-Khanjī.

Al-Nabhān, Muḥammad Fārūq. (1998). al-Fikr al-Khaldūnī Min Khilāl al-Muqaddimah. Beirut: Mu'assasah alRisālah.

Al-Shahrastānī, Muḥammad Ibn ${ }^{\mathrm{c} A b d}$ Al-Karīm. (1993). Al-Milal Wa Al-Nihal. Beirūt: Dār Al-Ma ${ }^{\mathrm{c}}$ rifah.

Al-Shik cah, Musțafā. (1992). Al-Usus Al-Islāmiyyah F̄̄ Fikr Ibn Khaldūn Wa Nazariyyātuhu. Cairo: Al-Dar AlMisriyyah Al-Lubnāniyyah.

Al-Shuwaykat, Sulaymān ${ }^{\mathrm{c} A b d u l l a ̄ h . ~(1986) . ~ M a n h a j ~ a l-M a s ~}{ }^{c} \bar{u} d \bar{\imath}$ Fì Kitābah al-Tārīkh. n.pl: n. pb.

Al-Ṭabbā' ${ }^{c}{ }^{c}$ Umar Fārūq. (1992). Ibn Khaldūn: F̄̄ S̄iratihi Wa Falsafatihi al-Tārīkhiyyah Wa al-Ijtimāciyyah. Beirut: Mu'assasah al-Macārif.

Al-Wāqidī, Muḥammad ibn ' Umar ibn Wāqid. (1984). Kitāb al-Maghāzī. n.pl.: c'̄̄lam al-Kutub.

Ali Husayn Wardi. (1950). A Sociological Analysis of Ibn Khaldun's Theory: A Study of the Sociology of Knowledge. PhD Thesis. The University of Texas.

Berg, Bruce L. (2001). Qualitative Research Methods for the Social Sciences. USA: Allyn and Bacon.

Black, Antony. (2005). The History of Islamic Political Thought: From the Prophet to the Present. Edinburgh: Edinburgh University Press.

Bland, Kalman. (1983). An Islamic Theory of Jewish History: The Case of Ibn Khaldun. Journal of Asian and African Studies. 18 (3/4): 189-197.

Campo, Juan E. (2009). Ibn Khaldun, Abd al-Rahman ibn Muhammad. In Campo, Juan E. (ed.). Encyclopedia of Islam. New York: Facts of File. 334-335.

Collingwood, R. G. (1970). The Idea of History. Oxford: Oxford University Press.

Donnelly, Mark and Norton, Claire. (2011). Doing History. London and New York: Routledge.

Fischel, Walter Joseph. (1967). Ibn Khaldun in Egypt: His Public Functions and Historical Research. Berkeley and Los Angeles: University of California Press.

Fuad Baali and Ali Wardi. (1981). Ibn Khaldun and Islamic Thought-Styles: A Social Perspective. Massachusetts: G.K. Hall and Co.

Hammond, Michael and Wellington, Jerry. (2013). Research Methodology: Key Concepts. London and New York: Routledge.

Hitti, Philip Khuri. (1946). History of the Arabs. London: MacMillan and Co., Limited.

Hitti, Philip Khuri. (1968). Makers of Arab History. London: MacMillan. 
Wan Mohd Fazrul Azdi \& Jaffary Awang / UMRAN - International Journal of Islamic and Civilizational Studies. 04-01 (2017) 67-79

Ibn Ḥazm. (1996). al-Fișal Fī al-Milal Wa al-Ahwā' Wa al-Nihal. Beirūt: Dār al-Jayl.

Ibn Khaldūn. (n.d). Tarīkh Ibn Khaldūn al-'`Ibar wa Diwān al-Mubtada’ Wa al-Khabar F̄̄ Ayyām al-'ªrab wa al${ }^{c}$ Ajam wa al-Barbar wa Man ${ }^{c} \bar{A}$ șarahum Min Dhawī al-Sulțān al-Akbar. Taḥīq: Abū Șuhayb al-Karamī. Riyadh: Bayt al-Afkār al-Dawliyyah.

Ibn Khaldun. (1967). The Muqaddimah: An Introduction to History. 3 vols. Princeton: Princeton University Press.

Ibn Khaldūn. (1979). al-Tacrīf Bi Ibn Khaldūn Wa Riḥlatuhu Gharban Wa Sharqan. Lubnan: Dar al-Kitab al-Lubnānī.

Ibn Khaldūn. (2001). Diwān al-Mubtada' Wa al-Khabar Fi Tarīkh al-'`Arab Wa al-Barbar Wa Man 'Āṣarahum Man Dhaw̄̄ al-Sha'n al-Akbar. Taḥqīq wa Murāja ${ }^{c}$ ah: Khalīl Shiḥādah dan Suhayl Zikār. Beirut: Dār al-Fikr.

Ibn Khaldūn. (2014). Al-Muqaddimah. (Taḥqīq: 'Alī cAbd al-Wāḥid Wāfì). 3 vols. Cairo: Maktabah Nahḍah Misr.

'Imād al-Dīn Khalīl. (1983). Ibn Khaldūn Islāmiyyan. Beirūt: al-Maktab al-Islāmī.

Ishak Saat. (2010). Penulisan Sejarah. Kuala Lumpur: Utusan Publications and Distributor Sdn. Bhd.

Issawi, Charles. (1963). An Arab Philosophy of History. London: John Murray.

Levy-Rubin, Milka. (2011). Non-Muslims in the Early Islamic Empire: From Surrender to Coexistence. Cambridge: Cambridge University Press.

Lutfi Sunar and Faruq Yaslicimen. (2008). The Possibilities of New Perspectives for Social Sciences: An Analysis Based on Ibn Khaldun's Theory of Umrân*. Asian Journal of Social Science 36: 408-433.

Majdan Alias. (2011). Al- Mas ${ }^{\complement} \bar{u} d \overline{1} ’ s$ Methodology in His Study of Religions Other Than Islam. Revelation and Science 1(3):108-114.

Mohammad Abdullah Enan. (1997). Ibn Khaldun: His Life and Works. New Delhi: Kitab Bhavan.

Muhammad Azizan Sabjan. (2010). Early Muslim Scholarship in Religionswissenschaft: A Study of Ibn Khaldun and Religious Institutions of Christianity. Jurnal Majlis Islam Sarawak 2(2): 1-8.

Muhsin Mahdi. (2016). Ibn Khaldun's Philosophy of History: A Study in the Philosophic Foundation of the Science of Culture. London and New York: Routledge.

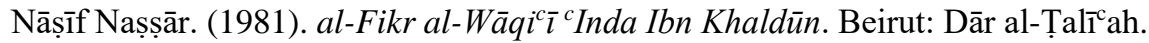

Ort, L. J. R. (1968). Mani, Manichaeism, 'Religionswissenschaft'. Numen 15: 191-207.

Pines, Solomon. (1970). Ibn Khaldun and Maimonides: A Comparison between Two Texts. Studia Islamica 32: 265274.

Pummer, Reinhard. (1972). Religionswissenschaft or Religiology? Numen. 19(2/3):91-127.

Qasim Ahmad. (1991). Karya Sejarah: Pendekatan dan Persoalan. Kuala Lumpur: Dewan Bahasa dan Pustaka.

Saleh Faghirzadeh. (1982). Sociology of Sociology: In Search of...Ibn-Khaldun's Sociology Then and Now. Tehran: The Soroush Press.

Schmidt, Nathaniel. (1978). Ibn Khaldun: Historian, Sociologist and Philosopher. Lahore: Universal Books.

Shafer, Robert Jones (1976). A Guide to Historical Method. Illinois: The Dorsey Press.

Syed Omar Syed Agil. (2008). The Muqaddimah of Ibn Khaldun: Religion, Human Nature and Economics. Kajang: Kolej Universiti Islam Antarabangsa Selangor.

Tritton, A. S. (2008). Caliphs and Their Non-Muslim Subjects: A Critical Study of the Covenant of 'Umar. London and New York: Routledge.

Turner, Bryan S. (1971). Sociological Founders and Precursors: The Theories of Religion of Emile Durkheim, Fustel De Coulanges and Ibn Khaldun. Religion 1(1): 32-48. 
Wan Mohd Fazrul Azdi \& Jaffary Awang / UMRAN - International Journal of Islamic and Civilizational Studies. 04-01 (2017) 67-79

Wasserstrom, Samuel M. (1999). Heresiography of the Jews in Mamluk Times. In Waardenburg, Jacques. (ed.) Muslim Perceptions of Other Religions. Oxford: Oxford University Press.

Whittingham, Martin. (2011). The Value of Tahrif $\mathrm{Ma}^{\mathrm{c}}$ nawi (corrupt interpretation) as a Category for Analysing Muslim Views of the Bible: Evidence from Al-Radd Al-Jamil and Ibn Khaldun. Islam and Christian-Muslim Relations 22(2): 209 -222.

Zaid Ahmad. (2003). The Epistemology of Ibn Khaldun. London \& New York: Routledge Curzon. 